\title{
In situ growth and chemical composition of the giant kelp, Macrocystis pyrifera: response to temporal changes in ambient nutrient availability
}

\author{
Richard C. Zimmerman \& James N. Kremer
}

Department of Biological Sciences, University of Southern California, Los Angeles, California 90089-0371, USA

\begin{abstract}
Temporal variations in growth of the giant kelp Macrocystis pyrifera were examined in relation to ambient nutrient availability and chemical composition of mature blades, the primary site of nutrient and carbohydrate storage in $M$. pyrifera. The effect of nutrient availability on growth was well approximated by a Monod rectangular hyperbola, with growth saturating at ambient nitrate concentrations between 1 and $2 \mu \mathrm{M}$. M. pyrifera was unable to generate nutrient reserves that would last beyond $30 \mathrm{~d}$. Nitrogen reserves were stored as free amino acids, and generally constituted about $10 \%$ of total tissue nitrogen. Total nitrogen content was never more than $2.5 \%$ of dry weight. There was no significant correlation between growth and tissue nitrogen. In contrast, carbohydrate levels were negatively correlated with growth rates, tissue nitrogen content, and ambient nutrient availability. Although concentrations of nitrogen and carbohydrate reserves showed familiar variations described for other kelps, the physical environment in southern California is probably not amenable to $M$. pyrifera making strategic use of these reserves. Nutrient availability appears to be too low to permit accumulation of more than $30 \mathrm{~d}$ reserve of nitrogen, and light levels are probably never low enough to make stored carbohydrate reserves necessary for survival.
\end{abstract}

\section{INTRODUCTION}

The giant kelp Macrocystis pyrifera is among the fastest growing and most productive of all macrophytes, creating great forests in subtidal rocky habitats in the temperate eastern Pacific. Intermittently, however, it experiences periods of reduced productivity in southern California. This decline usually occurs during the summer and fall, and is especially pronounced during El Nin̄o years (McFarland \& Prescott 1959, Jackson 1977, Zimmerman \& Kremer 1984, Zimmerman \& Robertson 1985). Previously, it has been attributed to high ambient water temperatures, although no detailed mechanisms for this temperature effect have been proposed or examined (Brandt 1923, McFarland \& Prescott 1959, Clendenning 1971, North 1971 , Lobban 1978). Recent evidence suggests that availability of dissolved nutrients may also play a significant role in regulating productivity of the giant kelp (Jackson 1977. Gerard 1982a, North \& Zimmerman 1984, Zimmerman \& Kremer 1984, Zimmerman \& Robertson 1985)

Predictable seasonal fluctuations in growth rates have been found in Laminaria spp., Desmarestia aculeata, and several subtidal fucoids (Black 1950, Suto 1951, Chapman \& Burrows 1971, Lüning 1971, Mann 1972, Lüning et al. 1973, Kain 1976, Chapman \& Craigie 1977). Generally, growth rates are high in the winter and early spring, and decline during summer. Often these growth patterns are accompanied by changes in nitrogen and carbon content within the plant, as nitrogen and carbohydrate reserves are alternately laid down during times of luxury uptake and production, and utilized at times of increased demand.

Nutrient availability was found to regulate the growth pattern of Laminaria longicruris (Chapman \& Craigie 1977, 1978). However, the generality of nutrient regulation has not always been supported by other studies. Buggeln (1978) was unable to increase growth rates of Alaria esculenta by fertilizing the plants with nitrogen, and in situ growth of $L$. pallida appears to be light limited (Diekmann 1980). There may be endogenous constraints on this cycle as well. $L$. hyperborea and $L$. saccharina are reported to grow slowly during the summer in Helgoland, even though ambient nutrient concentrations and light intensities 
appear to be more than adequate (Lüning 1979). Different temporal patterns in 3 populations of L. longicruris exposed to the same nutrient environment indicate some genetic control of this pattern as well (Gagne et al. 1982, Espinoza \& Chapman 1984).

In this study, growth rates and chemical composition of Macrocystis pyrifera were measured to determine whether their fluctuations were consistent with the temporal pattern of nutrient availability. We also were interested in determining under what conditions $M$. pyrifera would store reserves of nitrogen and carbon, and whether these storages played a significant role in maintaining growth rates during periods of potential resource limitation.

\section{MATERIALS AND METHODS}

Study site. The study site was located near the Catalina Marine Science Center of the University of Southern California, on the leeward side of Santa Catalina Island (Fig. 1). The kelp forest formed a $50 \mathrm{~m}$ wide bed running parallel to the shoreline in this region. Depths ranged from $3 \mathrm{~m}$ on the shoreward edge of the kelp forest to more than $15 \mathrm{~m}$ on the seaward edge. Longshore currents in the kelp forest were tidally controlled, running eastward on falling tides and westward on rising tides. Current speeds were frequently fast enough to submerge the canopy. The hydrographic simplicity and reduced influence of anthropogenic inputs and coastal effects made measurement of total system nutrient availability quite tractable, and the relatively oligotrophic nature of the waters surrounding Santa Catalina Island virtually guaranteed significant periods of low nutrient availability (Zimmerman \& Kremer 1984)

Nutrient availability and temperature. The temporal patterns of nutrient availability and ambient water temperature during the period of this study were analysed in detail by Zimmerman \& Kremer (1984) Nitrate concentrations and their associated ambient water temperatures were measured weekly from hydrocast samples using standard analytical techniques (Strickland \& Parsons 1972). Sampling bottles were fitted with reversing thermometers for measurement of water temperature in situ. Mean monthly nitrate availability in the upper $11 \mathrm{~m}$ of the water column was estimated from automatically recorded temperature profiles measured by a thermistor chain located at the seaward edge of the study site (at least 4500 observations $\mathrm{mo}^{-1}$ ) and the temperature-nitrate relation determined from the hydrocast samples.

Frond elongation. Estimates of frond elongation were made monthly from November 1980 to December

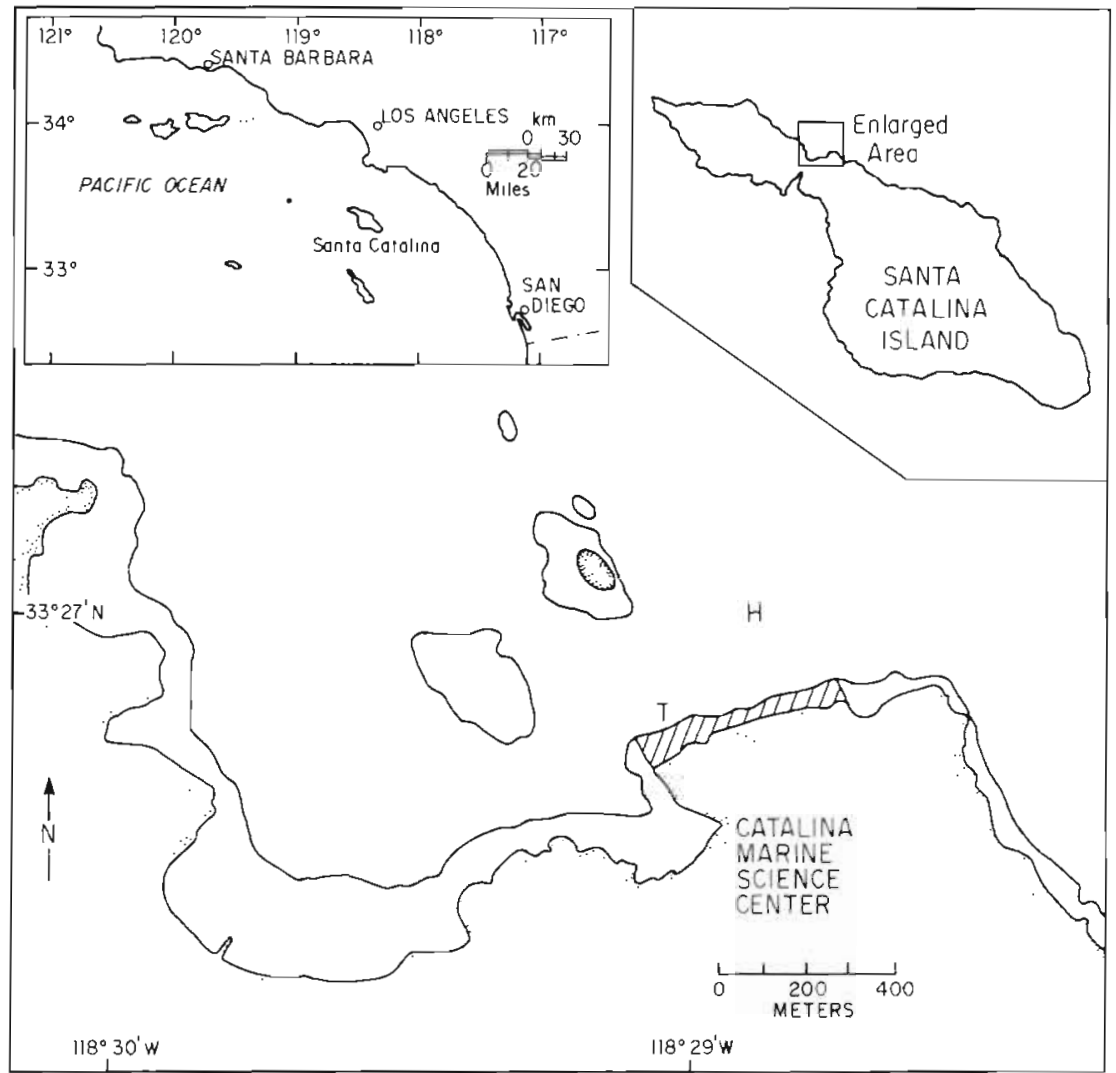

Fig. 1. Location of study site on Santa Catalina Island, indicated by crosshatched area. Depth contours indicate position of $60 \mathrm{~m}$ isobath. T and $\mathrm{H}$ refer to the location of the thermistor chain and hydrocast station, respectively 
1981. Ten plants with at least 20 fronds each were selected at random within the study site. Five subcanopy fronds (between 3 and $7 \mathrm{~m}$ long) were tagged on each plant by loosely tying a length of surveyor's flagging tape to each stipe approximately $1 \mathrm{~m}$ behind the growing tip once each month All 50 fronds were measured from the growing tip to the pneumatocyst just above the tag. The measurements were repeated 10 to $14 \mathrm{~d}$ later and the increase in distance from the tag to the tip of the frond was used as an index of frond elongation

Frond initiation. In addition to frond elongation, Macrocystis pyrifera grows by producing new fronds. Frond initiation rates were measured from February 1981 to December 1981 on the same plants used for measuring frond elongation. All fronds on each plant were counted at the beginning of each month. Fronds shorter than $1 \mathrm{~m}$ not already tagged were counted as new fronds and were tagged with surveyor's flagging tape. The frond initiation rate was simply the number of new fronds tagged each month.

Tissue chemistry. Analyses of tissue samples for chemical composition were carried out on mature, nonsenescent subcanopy blades collected 3 to $4 \mathrm{~m}$ from the apex of canopy fronds. These blades have been shown to have the highest rates of photosynthesis and nitrate uptake, as well as being the principal source of translocated photosynthate and nutrients (Wheeler 1978, Schmitz \& Srivastava 1979, Gerard 1982a). One such blade was collected each month from each of the 10 tagged plants for chemical analyses.

Mannitol and amino acids were extracted from $2.5 \mathrm{~g}$ of tissue cut from the middle of each blade, $10 \mathrm{~cm}$ from the pneumatocyst. Constituents were dissolved by 3 consecutive extractions in $25 \mathrm{ml}$ boiling ethanol for 15 min each. Compounds of interest extracted by this procedure included mannitol, free amino acids, and any inorganic nitrogen such as nitrate and ammonium (Chapman \& Craigie 1977, 1978). The 3 extracts were combined and diluted to $100 \mathrm{ml}$ with distilled water. Two $\mathrm{ml}$ of the combined extract were evaporated to dryness at $60^{\circ} \mathrm{C}$ and the residue redissolved in $50 \mathrm{ml}$ of distilled water.

Mannitol concentration of the extract was determined colorimetrically using the periodate-chromotropic acid method of Lambert \& Neish (1950) and a standard solution of D-mannitol. Amino acid concentration was determined on the same extract using fluorescamine and a glycine standard (North 1975). Nitrogen content was calculated from the concentration of fluorescamine positive material using a conversion factor of 1.2. This factor was obtained by comparing the reactivity of each amino acid present in the sieve tube sap of Macrocystis pyrifera, as listed by Schmitz \& Srivastava (1979), with glycine. The result- ing ratio of combined amino acid reactivity to glycine reactivity was found to be 1 . The conversion factor represents the ratio of nitrogen atoms to molecules of fluorescamine positive material, assuming that the relative abundance of each amino acid in the extract remained constant through time. Nitrate concentration of the extract was measured using standard analytical techniques (Strickland \& Parsons 1972).

Laminarin was extracted from the ethanol-insoluble residue by immersion in $25 \mathrm{ml}$ of $0.1 \mathrm{~N} \mathrm{NaOH}$ overnight, followed by homogenization in a tissue grinder. Alginate was precipitated by acidification with $10 \mathrm{~N}$ $\mathrm{HCl}$ and the solution diluted to $100 \mathrm{ml}$ with distilled water. The precipitate and cellular debris were removed from the solution by gravity filtration. Laminarin concentration of the filtrate was assayed colorimetrically using the anthrone reagent method of Yemn \& Willis (1954), with a D-glucose standard.

Carbon and nitrogen content were measured on discs cut from the same piece of tissue before extraction. The discs were dried at $60^{\circ} \mathrm{C}$ for $72 \mathrm{~h}$ and then ground to a fine powder with a glass mortar and pestle. The ground samples were frozen until analysed. Tissue concentrations of carbon and nitrogen were determined using a Perkin-Elmer Model $29 \mathrm{~B}$ elemental analyser. Some samples were run using an instrument on loan to USC and others were processed by the Marine Science Institute Analytical Laboratory, U. C. Santa Barbara. Intercalibration standards were run to verify consistency between instruments.

Statistical analyses. Monod parameters were estimated by the Marquardt algorithm, a non-linear, direct-fit method (Bevington 1969), using the residual error variance $\left.\left(\sum_{i=1}^{n} \text { (Observed-Predicted }\right)^{2} /(n-1)\right)$ for the goodness-of-fit criterion. Statistical significance of temporal variability was determined for all time series using Model I ANOVA and the Student-NewmannKeuls (SNK) multiple comparison test (Sokal \& Rohlf 1969). Data were transformed as needed based on preliminary analyses. The angular transformation was applied to percentage data to assure normal distributions and some data were log-transformed to assure independence of variances and means before application of ANOVA (Sokal \& Rolf 1969). Product-moment correlation coefficients ( $r$ ) were calculated for certain pairs of variables.

\section{RESULTS}

\section{Nutrient availability}

Ambient concentrations of dissolved nitrate were characteristically high during the winter and spring, and generally low (less than $1.0 \mu \mathrm{g}$-at $\mathrm{N}^{-1}$ ) during the 


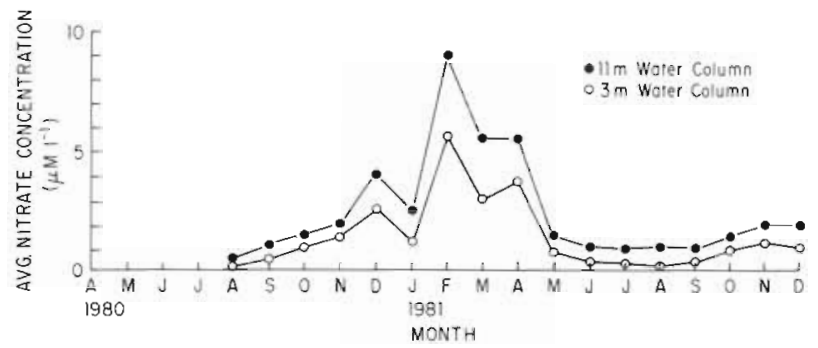

Fig. 2. Estimates of mean monthly nitrate concentrations for water columns of $3 \mathrm{~m}$ and $11 \mathrm{~m}$. Estimates were calculated from the temperature-nitrate relation and high frequency temperature profiles described by Zimmerman \& Kremer (1984)

summer and fall (Fig. 2). Nutrient availability increased with depth. During the winter, nitrate availability was controlled by large-scale horizontal advection and storm-induced vertical mixing. During the summer and fall, hydrography was dominated by strong thermal stratification; and nitrate was provided to the kelp zone by periodic vertical excursions of the thermocline. These processes were discussed in detail by Zimmerman \& Kremer (1984)

\section{Frond elongation rates}

Growth rates were highest in the winter and spring, and lowest in the summer (Fig. 3). The relation between nitrate availability and growth rates was well

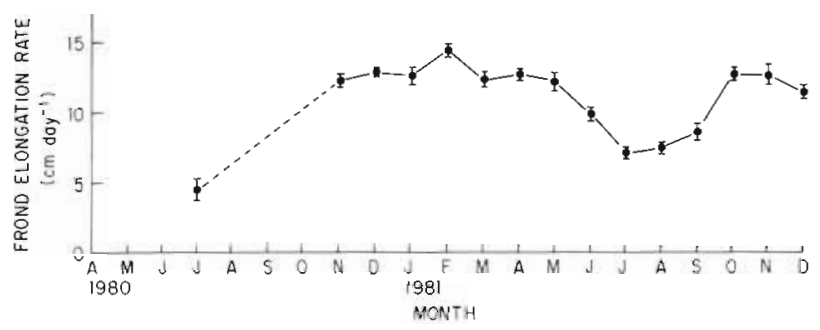

Fig. 3. Temporal pattern of variability in frond elongation rates. Error bars indicate $\pm 1 \mathrm{SE}$ of the mean

approximated by a Monod rectangular hyperbola, although field conditions did not permit measurement of growth rates below the estimated half-saturation constant. The maximum elongation rate $\left(\mathrm{V}_{\max }\right)$ was $14.3 \mathrm{~cm} \mathrm{~d}^{-1}$, the half-saturation constant $\left(\mathrm{k}_{\mathrm{s}}\right)$ was 0.26 $\mu \mathrm{MNO}_{3}$, and the residual variance was 0.72 (Fig. 4).

The relation between temperature and growth (Fig. 5) appears to be a mirror image of Fig. 4 as might be expected from the strong inverse relation between temperature and nitrate (Zimmerman \& Kremer 1984). However, while the relation between growth and nu-

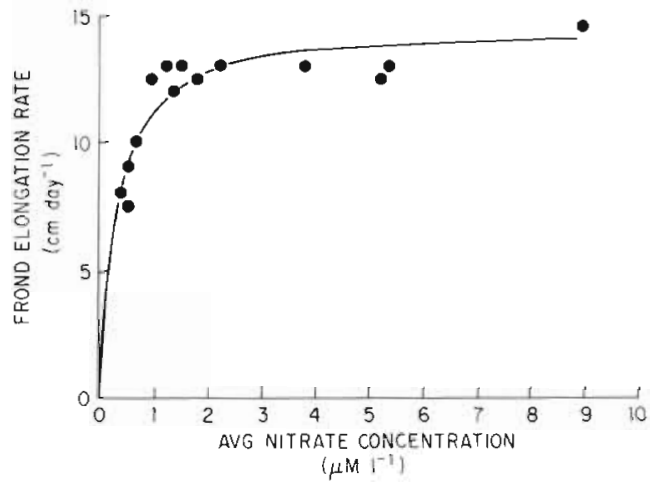

Fig. 4. Frond elongation rates plotted as a function of ambient nitrate concentration. Monod parameters were derived using the Marquardt algorithm, a non-linear, direct fit method using a residual variance criterion for goodness-of-fit

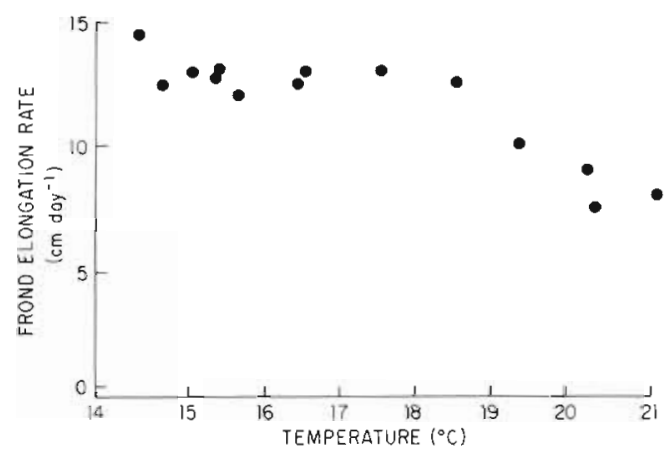

Fig. 5. Frond elongation plotted as a function of temperature

trient availability was explained easily by the Monod model, the relation between temperature and frond elongation did not exhibit a typical physiological temperature response (Fig. 5). Growth was constant between $14.5^{\circ} \mathrm{C}$ and $18.5^{\circ} \mathrm{C}$. Above that, growth declined linearly with temperature.

\section{Frond initiation}

The relation between nutrient availability and frond initiation rates was not as strong. Mean plant size and frond initiation rates began to drop in June 1981 (Fig. 6). This was associated with the nutrient-poor conditions that persisted from May to December 1981. Although frond elongation rates recovered with the onset of greater nutrient availability in the fall, frond initiation rates and mean plant sizes did not.

Frond initiation rates suggest a hyperbolic relation with nitrate availability (Fig. 7). However, the lack of data between 1.5 and $5 \mu \mathrm{M}$ nitrate preclude much confidence in the parameter values. The maximum reliable rate of frond initiation is near 8 fronds plant ${ }^{-1}$ $\mathrm{m}^{-1}$, with a $\mathrm{k}_{\mathrm{s}}$ near $0.8 \mu \mathrm{M}$ nitrate. 


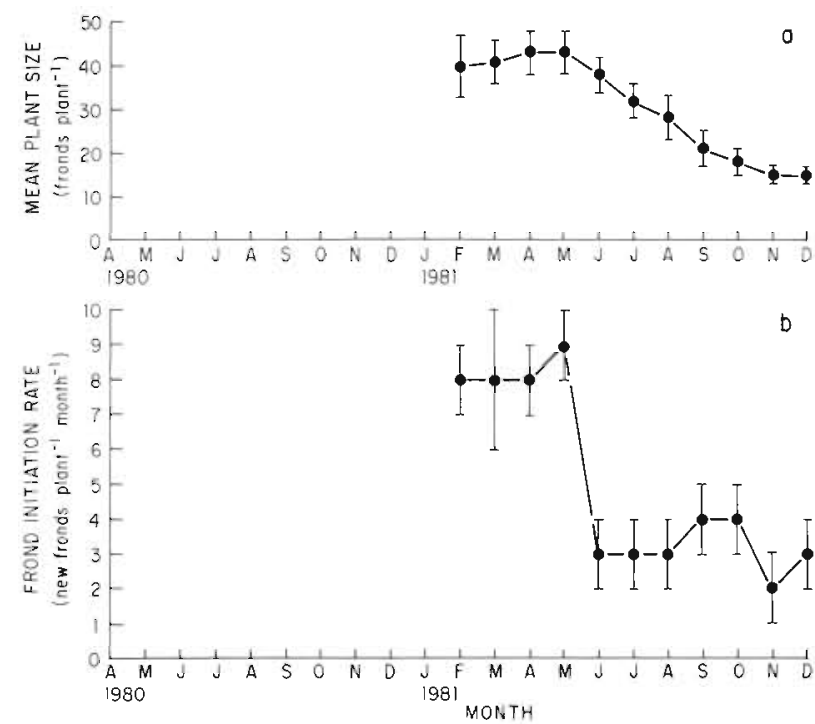

Fig. 6. Temporal pattern in (a) mean plant size and (b) frond initiation rates. Error bars indicate $\pm 1 \mathrm{SE}$ of the mean

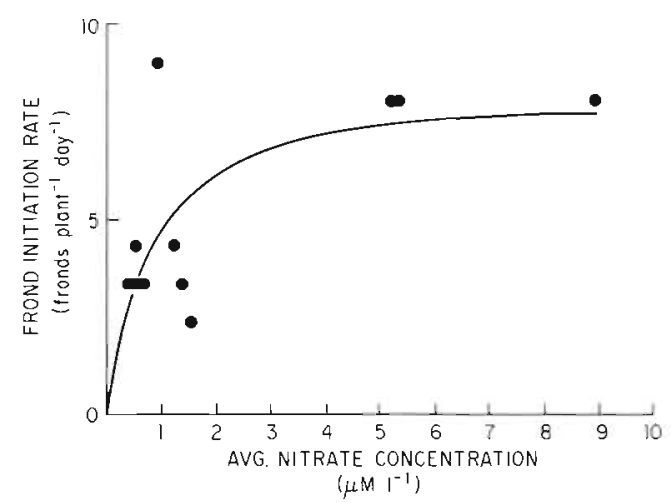

Fig. 7. Frond initiation rates plotted as a function of ambient nitrate concentration. Monod parameters were generated using the same algorithm as in Fig. 4, although the limited data make the hyperbolic nature of the relation less secure

\section{Tissue nitrogen}

Total tissue nitrogen and amino acid content of mature kelp blades showed significant variation over time (Fig. 8A, B). Nitrogen content was highest in winter and spring and lowest during summer and fall, and showed the same magnitude of variation as the growth rate measurements $(2.5 \times$ minimum value $)$. Tissue nitrogen was not correlated significantly with ambient nutrient availability ( $\mathrm{r}=0.34, \mathrm{n}=17$ ), with frond elongation $(r=-0.07)$ or with frond initiation $(r=0.09)$. However, when tissue nitrogen was related to nutrient availability during the previous month, the correlation increased dramatically $(\mathrm{r}=0.68, \mathrm{P}<0.01$, $n=16$ ). There did not appear to be a similar response lag between nitrogen content and growth rate $(\mathrm{r}=0.06)$.

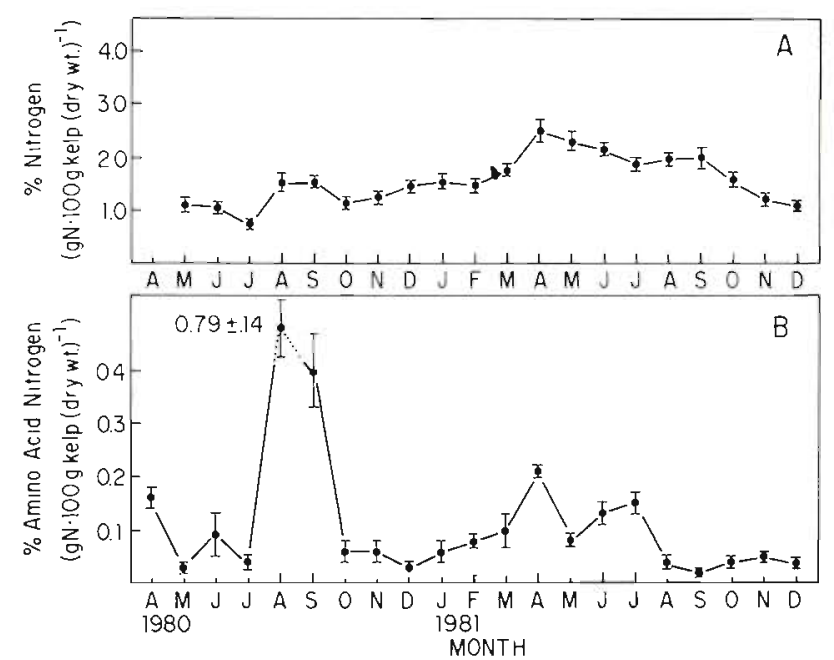

Fig. 8. Temporal pattern of variability in (A) tissue nitrogen quota and (B) amino acid content. Errors bars indicate $\pm 1 \mathrm{SE}$ of the mean

Labile amino acids appear to be the major nitrogen storage product found in plants at this study site. Ethanol extracts were assayed regularly for nitrate but measurable quantities were never found. Amino acid content was more variable than total tissue nitrogen, and maximum levels were measured during August and September 1980 (Fig. 8B). There were 2 other (much smaller) peaks during April and July of 1981. The April peak is easily explained as nitrogen storage during a period of high nitrate availability, high tissue nitrogen content and high growth rates. Reasons for the August-September 1980 and July 1981 peaks are not clear. While analytical error cannot be ruled out in the former case, increased amino acid levels during July 1981 may represent mobilization of stored protein to support growth during the summer.

Changes in amino acid concentration fluctuated over a range of 20 times the lowest measured value, excluding August and September 1980. By comparison, total tissue nitrogen showed only a 2.5 -fold variation. The proportion of total tissue nitrogen represented by the free amino acid pool was generally around $10 \%$. It made up half of the total tissue N during August 1980, and was as low as $1 \%$ in September 1981. The relation between amino acid content and total nitrogen was statistically significant $(\mathrm{r}=0.39, \mathrm{P}<0.01, \mathrm{n}=197)$, although not reliable enough to form the basis of a predictable relation. The relation between growth and amino acid content was not statistically significant $(\mathrm{r}=-0.06)$.

\section{Tissue carbon}

Carbon content was less variable than nitrogen - the maximum value was only about 1.7 times the 
minimum. Tissue carbon levels peaked in July 1980 at $33 \%$ of dry weight, and declined gradually for the next 10 mo (Fig. 9 A). Temporal variations in carbon content were generally opposite those of nitrogen, as indicated by a significant, though hardly predictive, negative correlation between them $(\mathrm{r}=-0.37, \mathrm{P}<0.01, \mathrm{n}=$ 194). Carbon content was highest just 1 mo before the peak in amino acid concentration, and began its $10 \mathrm{mo}$ decline in late summer, during this extremely high peak in amino acid content. Lowest carbon levels occurred during the summer and fall of 1981, when tissue nitrogen was relatively high.

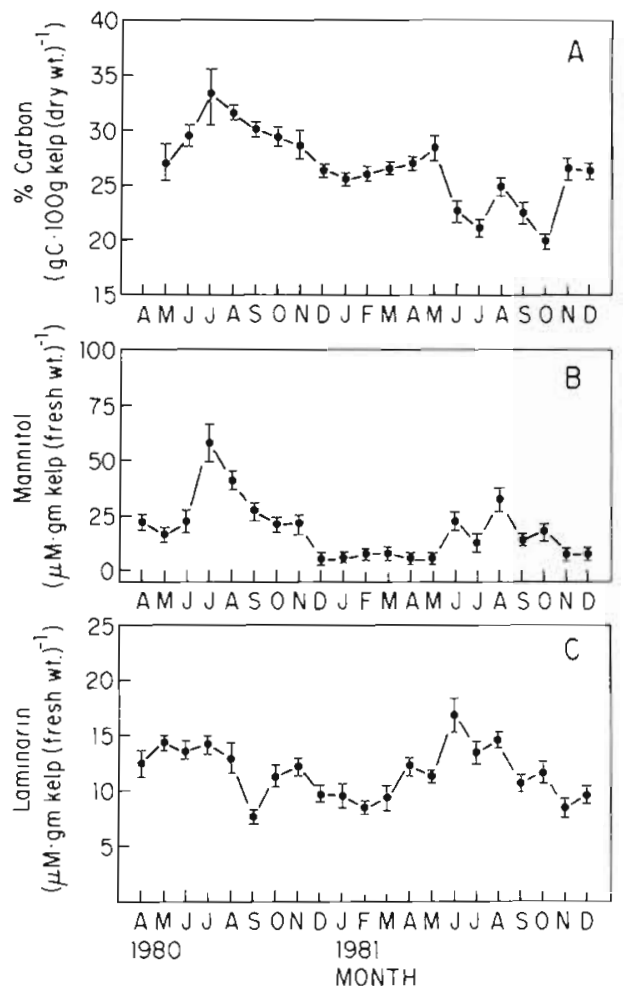

Fig. 9. Temporal pattern of variability in (A) carbon content, (B) mannitol content, and (C) laminarin content. Error bars indicate $\pm 1 \mathrm{SE}$ of the mean

Temporal variation in mannitol concentration was similar to carbon, and there was a significant positive correlation between them $(r=0.43, \mathrm{P}<0.01, \mathrm{n}=187)$. However, mannitol concentrations were much more labile (Fig. 9 B). The highest monthly mean value (July 1980) was 6 times the lowest monthly mean value recorded during the winter of 1981. Mannitol was negatively correlated with ambient nitrate concentration ( $\mathrm{r}=-0.52, \mathrm{P}<0.05, \mathrm{n}=15$ ), frond elongation rate $(r=-0.81, P<0.01, n=13)$, and total tissue nitrogen ( $\mathrm{r}=-0.32, \mathrm{P}<0.001, \mathrm{n}=192)$. Mannitol concentrations increased when growth rates and tissue nitrogen declined, and were lowest when nutrient availability, growth rates, and tissue nitrogen concentrations were high.

The temporal pattern in laminarin concentration was slightly different (Fig. 9 C). While laminarin was correlated significantly with mannitol $(r=0.37, P<0.01$, $n=191)$ and frond elongation rates $(r=-0.68, P$ $<0.05, \mathrm{n}=13$ ), changes in laminarin and mannitol did not occur at the same time. Laminarin concentrations remained constant during the early summer of 1980 , while mannitol concentrations increased by a factor of 4 . While mannitol concentrations declined during the fall of 1980 and remained low through the spring of 1981, laminarin concentrations actually increased during the fall of 1980 and decreased only slightly during the winter of 1981.

\section{DISCUSSION}

Seasonal fluctuations in growth rates of Macrocystis pyrifera at Santa Catalina Island appear to be typical of many macrophytes (Chapman 1974), although this pattern has not always been reported for Macrocystis in southern California. Wheeler \& North (1981) found no significant seasonal variation in growth rate along the southern California mainland during 1975 and 1976 despite some evidence for a temporal signal in dissolved nitrate. Kelp growth rates were low at Catalina only when ambient nitrate concentrations for the whole water column averaged less than $1.5 \mu \mathrm{Ml}^{-1}$ for a month or longer, while nitrate concentrations along the mainland were probably higher than that most of the time during the summer of 1975 (Wheeler \& North 1981, Zimmerman \& Kremer 1984).

Our estimate of the threshold for nitrate limitation of adult Macrocystis pyrifera in the field is an order of magnitude lower than estimates made from laboratory culture studies using juvenile plants (Manley \& North 1984), and probably reflects differences in the ratio of source:sink tissue in adults and juveniles. The actual values of $k_{s}$ and $V_{\max }$ are different from those we reported earlier (Zimmerman \& Kremer 1984) and represent the effect of different curve-fitting techniques on parameter estimation. The smaller residual variance here indicates that the direct-fit method produced a better estimate of the parameters than does the Wolf linearization plot used earlier.

Kelp growth rates at Catalina were not related to changes in nitrogen content of the mature blades, which is contrary to previous work on plant/nutrient interactions (e.g. Wheeler \& North 1980, Manley \& North 1984). While mature blades of Macrocystis pyrifera appear to be the principal nutrient storage tissues for the plant (Gerard 1982a), they do not possess growing meristematic tissue (Lobban 1978). As such, they 
should be the first to lose tissue nitrogen when demand exceeds supply, and should be the last to build reserves when nutrients are available in excess. Close examination of our time series data of nitrate availability, growth, and tissue nitrogen tend to support this hypothesis. Growth rates were high throughout the fall of 1980 and into 1981, while tissue nitrogen content did not increase until April. Afterwards, tissue nitrogen declined throughout the year while growth rates were low only through the summer and increased during autumn

Macrocystis pyrifera should be capable of building significant internal reserves of nitrogen under conditions of high nitrate availability, comparing the halfsaturation constants and saturation points for growth $\left(\mathrm{k}_{\mathrm{s}}=0.26\right.$ and $0.79 \mu \mathrm{M} \mathrm{NO}_{3}$ for frond elongation and initiation; sat. pt. $=1.5$ to 2 and 1.5 to $3 \mu \mathrm{M} \mathrm{NO}$ respectively) with those for nutrient uptake $\left(\mathrm{k}_{\mathrm{s}}=8\right.$ to $13 \mu \mathrm{M} \mathrm{NO}$, sat. pt. $=15$ to $20 \mu \mathrm{M} \mathrm{NO}$ : Haines \& Wheeler 1978, Wheeler 1978, Gerard 1982b). However, $M$. pyrifera appears unable to accumulate large nitrogen reserves in southern California. The plants in this study maintained high growth rates for 1 mo after the onset of extremely low nutrient availability in June $1981\left(\approx 1 \mu \mathrm{M} \mathrm{NO}_{3}\right.$ ), and nitrogen reserves lasted only 2 wk in a specimen of $M$. pyrifera transplanted by Gerard (1982a) from more eutrophic conditions near the southern California mainland to an essentially zero nutrient environment near Santa Catalina Island. In contrast, internal nitrogen reserves of Laminaria Iongicruris, which are stored primarily as soluble nitrate, seem capable of supporting high growth for at least 2 mo (Chapman \& Craigie 1977).

Dissolved nitrate has not been found in Macrocystis pyrifera growing in southern California (Wheeler \& North 1981, this study). However, Wheeler \& Srivastava (1984) found nitrate to represent as much as $66 \%$ of the soluble nitrogen in $M$. integrifolia growing near Vancouver Island, B. C. At least 5 species of perennial macroalgae growing in Rhode Island Sound also store large quantities of nitrate during the winter (Asare \& Harlin 1983). Their studies were all performed at much higher latitudes, where low winter insolation can be even further reduced by prolonged cloud cover and/or ice formation at the sea surface (Hatcher et al. 1977 . Smith et al. 1983). Light-limitation of the nitrate reduction pathway (Haxen \& Lewis 1981, Davison \& Stewart 1984), low demand for nitrogen relative to the high growth period of late winter and spring, and high nutrient availability beginning in early winter may result in storage of significant amounts of nitrate within the tissues of these algae. In southern California, high growth rates throughout the winter, high winter surface irradiances $\left(\approx 1000 \mu \mathrm{E} \mathrm{m}^{-2} \mathrm{~s}^{-1}\right)$, and lower mean nutrient availability during the winter may keep the ratio of nitrogen uptake to demand at a point that prevents the accumulation of large pools of labile nitrogen, especially the inorganic forms. This may further explain the relatively small size of the labile nitrogen fraction and the inability of $M$. pyrifera to withstand extended periods of nutrient limitation in southern California (Gerard 1982a, Zimmerman \& Robertsan 1985)

Tissue concentrations of mannitol and laminarin increased during the summer, when growth rates were low, and were reduced (presumably to support growth) during the winter and spring, when growth rates were high. Although photosynthesis was not light limited in the surface canopy during winter, the carbohydrate reserves probably were translocated to support growth of the shaded subcanopy fronds. The seasonal cycle of carbon storage in Laminaria saccharina is similar qualitatively, although its amplitude of variation is greater and it appears to be more dependent on summer accumulation of carbohydrates to support growth during the early winter than Macrocystis pyrifera (Hatcher et al. 1977, Chapman \& Craigie 1978).

It had been reported that Macrocystis pyrifera stored almost none of its carbohydrate reserve in the form of laminarin (Lindner et al. 1977). However, we found the laminarin pool to constitute $30 \%$ to $50 \%$ of the carbohydrate reserve, on average. Although mannitol and laminarin concentrations were correlated with tissue carbon content and with each other, interesting differences in temporal patterns of these 2 carbohydrates may be explained by their different properties. Laminarin is not translocatable, but must be converted into mannitol before it can be transported for use throughout the plant (Craigie 1974, Schmitz \& Srivastava 1979). During periods of carbon storage, we found that laminarin concentrations increased first, followed by mannitol only after the laminarin pool reached 12 $\mu \mathrm{M}(\mathrm{g} \mathrm{kelp})^{-1}$ in the mature blades. When carbohydrate reserves dropped, mannitol was utilized first, probably because of its more labile nature, with laminarin being mobilized only after mannitol concentrations decreased.

It is difficult to separate the effects of temperature and nutrients on growth from these data alone because ambient temperature and nitrate concentration were highly correlated (Zimmerman \& Kremer 1984), however the combined evidence for nutrient limitation is strong. Maximum rates of photosynthesis and phosphate uptake potentials of Macrocystis spp. increase with temperature up to at least $20^{\circ} \mathrm{C}$ when exposed to short-term temperature changes in the laboratory (Smith et al. 1983, Arnold \& Manley 1985). Zimmerman (1983) reported a ratio of daily photosynthesis to respiration of about 4 throughout the year during 1981, even when ambient surface temperatures were as high as 
$23^{\circ} \mathrm{C}$. Furthermore, rates of chlorophyll-specific photosynthesis measured in situ increased with ambient water temperature during the extremely warm water period associated with El Niño in 1983 (Gerard 1984). Finally, application of nutrients in situ have been shown to maintain canopy density and increase growth rates during the summer when water temperatures were high (Zimmerman 1983, North \& Zimmerman 1984).

Like many algae, Macrocystis pyrifera seems to be quite plastic. Its variable morphology has been attributed to the local physical environment (Kain 1982). It is now evident that productivity and chemical composition of the giant kelp are similarly affected by variations in the local environment. Unlike other kelps, however, $M$. pyrifera seems unable to make strategic use of its nitrogen and carbon reserves in southern California. The nutrient environment is comparatively poor, with extended periods of limitation occurring on time scales that are unpredictable with respect to individual plants. This, coupled with high irradiances year-round probably make building strategic nutrient reserves difficult and carbohydrate reserves irrelevant. Although its relative importance probably varies between years and locations, nutrient limitation is clearly an important regulator of kelp forest productivity in southern California.

Acknowledgements: Financial support was provided by the A.R.C.S. Foundation of Los Angeles, Sigma Xi, the Scientific Research Society, and the Institute of Marine and Coastal Studies of the University of Southern California. Thanks to T. Dean, V Gerard, S. Manley and W. North for critical comments and suggestions, and to colleagues within the Department of Biological Sciences for aid in collecting the data. Contribution No. 102 from the Catalina Marine Science Center, University of Southern California.

\section{LITERATURE CITED}

Arnold, K. E., Manley, S. L. (1985). Carbon allocation in Macrocystis pyrifera (Phaeophyta): intrinsic variability in photosynthesis and respiration. J. Phycol. 21: 154-167

Asare, S. O., Harlin, M. M. (1983). Seasonal fluctuations in tissue nitrogen for five species of perennial macroalgae in Rhode Island Sound. J. Phycol. 19: 254-257

Bevington, P. R. (1969). Data reduction and error analysis for the physical sciences. McGraw Hill, New York

Black, W A. P. (1950). The seasonal variation in weight and chemical composition of the common British laminariaceae. J. mar biol. Ass. U. K. 29: 45-72

Brandt, R. P. (1923). Potash from kelp. Early growth and development of the giant kelp, Macrocystis pyrifera. Bull. U. S. Dept. Agriculture 1191: 1-40

Buggeln, R. G. (1978). Physiological investigations on Alaria esculenta (Laminariales, Phaeophyceae). IV Inorganic and organic nitrogen in the blade. J. Phycol. 14: 156-160

Chapman, A. R. O. (1974). The ecology of macroscopic marine algae. Ann. Rev. Ecol. Syst. 5: 65-80

Chapman, A. R. O., Burrows, E. M. (1971). Field and culture studies of Desmarestia aculeata (L.) Lamour. Phycologia 10: $63-76$

Chapman, A. R. O., Craigie, J. S. (1977). Seasonal growth in Laminaria longicruris: relations with dissolved inorganic nutrients and internal reserves of nitrogen. Mar. Biol. 40: $197-205$

Chapman, A. R. O., Craigie, J. S. (1978). Seasonal growth in Laminaria longicruris: relations with reserve carbohydrate storage and nitrogen production. Mar. Biol. 46: 209-213

Clendenning, K. A. (1971). Photosynthesis and general development in Macrocystis. In: North, W J., (ed.) The biology of giant kelp beds (Macrocystis) in California. Beih. Nova Hedwigia 32, Cramer, Lehre, p. 169-190

Craigie, J. S. (1974). Storage products. In: Stewart, W. D. P (ed.) Physiology and biochemistry. Bot. Mono. 10, University of California Press, Berkeley, p. 206-236

Davison, I. R., Stewart, W. D. P. (1984). Studies on nitrate reductase activity in Laminaria digitata (Huds.) Lamour. I. Longitudinal and transverse profiles of nitrate reductase activity within the thallus. J. exp. mar. Biol. Ecol. 74 201-210

Diekmann, G. S. (1980). Aspects of the ecology of Laminaria pallida (Grev.) J. Ag. off the Cape Peninsula (South Africa). I. Seasonal growth. Botanica mar. 23: 579-585

Espinoza, J., Chapman, A. R. O. (1984). Ecotypic differentiation of Laminaria longicruris in relation to seawater nitrate concentration. Mar. Biol. 74: 213-218

Gagne, J. A., Mann, K. H., Chapman, A. R. O. (1982). Seasonal patterns of growth and storage in Laminaria longicruris in relation to differing patterns of availability of nitrogen in the water. Mar. Biol. 69: 91- 101

Gerard, V. A. (1982a). Growth and utilization of internal nitrogen reserves by the giant kelp Macrosystis pyrifera in a low nitrogen environment. Mar. Biol. 66: 27-35

Gerard, V. A. (1982b). In situ rates of nitrate uptake by the giant kelp, Macrocystis pyrifera (L.)C. Agardh: tissue differences, environmental effects, and predictions of $\mathrm{N}$ limited growth. J. exp. mar. Biol. Ecol. 62: 211-224

Gerard, V. A. (1984). Physiological effects of El Niño on giant kelp in southern California. Mar. Biol. Lett. 5: 317-322

Hatcher, B. G., Chapman, A. R. O., Mann, K. H. (1977). An annual carbon budget for the kelp Lamianria longicruris. Mar. Biol. 44: 85-96

Haines, K. C., Wheeler, P. A. (1978). Ammonium and nitrate uptake by the marine macrophytes Hypnea musciformis (Rhodophyta) and Macrocystis pyrifera (Phaeophyta). J. Phycol. 14: 319-324

Haxen, P. G., Lewis, O. A. M. (1981). Nitrate assimilation in the marine kelp, Macrocystis angustifolia (Phaeophyceae). Botanica mar. 24: 631-635

Jackson, G. A. (1977). Nutrients and production of giant kelp, Macrocystis pyrifera off southern California. Limnol. Oceanogr 22: 979-995

Kain, J. M. (1976). The biology of Laminaria hyperborea. VIII. Growth on cleared areas. J. mar biol. Ass. U. K. 56: $267-290$

Kain, J. M. (1982). Morphology and growth of the giant kelp, Macrocystis pyrifera in New Zealand and California. Mar. Biol. 67: 143-157

Lambert, M. Neish, A. C. (1950). Rapid method for estimation of glycerol in fermentation solutions. Can. J. Res. 28 : 83-89

Lindner, E., Dooley, C. A., Wade, R. H. (1977). Chemical variation of chemical constituents in Macrocystis pyrifera. Ocean Food and Energy Project Final Report. Naval Undersea Center, San Diego, California 92132, p. 1-22 
Lobban, C. S. (1978). The growth and death of the Macrocystis sporophyte. Phycologia 17: 196-212

Lüning. K. (1971). Seasonal growth of Laminaria hyperborea under recorded underwater light conditions near Helgoland. 4th Europ. Mar. Biol. Symp. Cambridge Univ. Press, London, p. 347-361

Lüning, K. (1979). Growth strategies of three Laminaria species (Phaeophyceae) inhabiting different depth zones in the sublittoral region of Helgoland (North Sea). Mar. Ecol. Prog. Ser. 1: 195-207

Lüning, K. Schmitz, K., Willenbrink, J. (1973). CO fixation and translocation in benthic marine algae. III. Rates and ecological significance of translocation in Laminaria hyperborea and L. saccharina. Mar. Biol. 23: 275-281

Mann, K. H. (1972). Ecological energetics of the seaweed zone in a marine bay on the Atlantic coast of Canada. II Productivity of the seaweeds. Mar. Biol. 14: 199-209

Manley, S. L., North, W. J. (1984). Phosphorus and the growth of juvenile Macrocystis pyrifera (Phaeophyta) sporophytes. J. Phycol. 20: 389-393

McFarland, W. N., Prescott, J. (1959). Standing crop, chlorophyll content and in situ metabolism of a giant keip community in southern California. Tex. Univ. Inst. Mar. Sci. Publ. 6: 109-132

North, B. B. (1975). Primary amines in California coastal waters: utilization by phytoplankton. Limnol. Oceanogr. 20: $20-27$

North, W. J. (1971). Growth of individual fronds of the mature giant kelp, Macrocystis. In: North, W. J., (ed.) The biology of giant kelp beds (Macrocystis) in California. Beih. Nova Hedwigia 32, Cramer, Lehre, p. 123-168

North, W. J., Zimmerman, R. C. (1984). Influences of macronutrients and water temperatures on summertime survival of Macrocystis canopies. Hydrobiologia 116/117: 419-424

Schmitz, K., Srivastava, L. M. (1979). Long distance transport in Macrocystis integrifolia. I. Translocation of $14-\mathrm{C}$ labelled assimilates. Pl. Physiol. 63: 995-1002
Smith, R. G., Wheeler, W. N., Srivastava, L. M. (1983). Seasonal photosynthetic performance of Macrocystis integrifolia (Phaeophyceae). J. Phycol. 19: 352-359

Sokal, R. R., Rohlf, F. J. (1969). Biometry. Freeman, San Francisco

Strickland, J. D. H., Parsons, T. R. (1972). A practical handbook of seawater analysis. Bull. Fish. Res. Bd Can. 167

Suto, S. (1951). On the growth of 'buds'in Hijikia fusiformis. Bull. Jap. Soc. Scient. Fish. 17: 13-14

Wheeler, P. A., North, W. J. (1980). Effect of nitrogen supply on nitrogen content and growth rates of juvenile Macrocystis pyrifera (Phaeophyta) sporophytes. J. Phycol. 16: $577-582$

Wheeler, P. A., North, W. J. (1981). Nitrogen supply, tissue composition and frond growth rates for Macrocystis pyrifera off the coast of southern California. Mar. Biol. 64: $59-69$

Wheeler, W. W. (1978). Ecophysiological studies of the giant kelp, Macrocystis. Ph. D. thesis. Univ, of California, Santa Barbara, p. 1-179

Wheeler, W. N., Srivastava, L. M. (1984). Seasonal nitrate physiology of Macrocystis integrifolia Bory. J. exp. mar. Biol. Ecol. 76: 35-50

Yemn, E. W., Willis, A. J. (1954). The estimation of carbohydrates in plant extracts by anthrone. Biochem. J. 57 : 508-514

Zimmerman, R. C. (1983). Seasonal patterns in the productivity of a giant kelp (Macrocystis pyrifera) forest: the effect of nutrient availability. Ph. D. Thesis. Univ. of Southern California, p. 1-182

Zimmerman, R. C., Kremer, J. N. (1984). Episodic nutrient supply to a kelp forest ecosystem in southern California J. mar. Res. 42: 591-604

Zimmerman, R. C., Robertson, D. L. (1985). Effects of El Niño on local hydrography and growth of the giant kelp, Macrocystis pyrifera at Santa Catalina Island, California. Limnol. Oceanogr. 30: 1298-1302 